\title{
Experts and academics as ideas generators and promulgators: identifying the social policy community of the European Union
}

\author{
Ryosuke Amiya-Nakada* \\ Tsuda College
}

\section{Introduction ${ }^{1}$}

One of the most intensively investigated topics in the field of European integration research is the influence of EU-level developments on national-level polity, politics and policies. The study of so-called "Europeanization" is a prominent example. In light of recent criticisms and modifications, its original image of the Europeanization process, exemplified by the "goodness-of-fit" hypothesis, reflects a rather formal-institutional and staged model of policy process. Namely, the policy is determined at the EU level at first, then the task of implementation falls on the member states and the analytical focus is on how they react to that specific EU legislation.

In some policy areas, however, this model does not fit neatly. It may be useful in the policy areas where the EU has extensive formal legislative responsibility and power, as in the case of competition policy. In contrast, those policy areas where the EU has weak rule-making power, the policy instruments of the EU institutions, especially those of the Commission, include necessarily soft ones. Thus, "New Modes of Governance" attract the attention of practitioners and researchers. In this "soft" channel of influence, it is quite difficult to specify the exact channel and measure the extent of European influence on national changes. This article is an attempt to identify one possible channel of transnational policy diffusion and suggest the possible conditions shaping its effectiveness.

For this type of investigation, the Advocacy Coalition Framework (ACF) is of help. Its initial intention was to move beyond the formal institutional power analysis, like the President versus the Congress, the Iron Triangle, etcetera. This fits nicely with our concern of paying more attention to the transnational and informal aspects of policy dynamics in the European Union. The ACF explicitly aimed at including an intergovernmental dimension and expanding the analytical focus to include journalists, analysts, researchers and others (Sabatier and Jenkins-Smith 1993, 24).

There are, however, a few differences in terms of academic concern and the institutional settings. First, the concern of this article is more about continuity and evolution than change. Second, the ACF usually presupposes two or three competing advocacy coalitions. In our case, this does not apply, as will be discussed in the third section of the article. Third, the institutional architecture of the EU is more complex and fragmented. In addition, due to the multi-level nature of the EU, it cannot be assumed a priori that an advocacy coalition includes actors from different levels. Brussels is more distant to the EU citizens

\footnotetext{
* Professor, Department of International and Cultural Studies, Tsuda College 1 This is a slightly revised version of my paper delivered at the fifth General Conference of the European Consortium for Political Research, September 10-12, 2009 in Potsdam. I thank Nils Bandelow and Oliver Fueg for inclusion in their panel. I am also grateful to Hugo Dobson for his help in editing and proofreading the article.
} 
than Washington D. C. is to US citizens. Our strategy is to focus on the EU level at first, then examine its "reach" beyond Brussels.

Because of these differences, we use the ACF just as a reference, and avoid directly "applying" the framework to our case. And we use the term "policy community" as a descriptive concept for a set of people with shared values and orientations, operating in the policy subsystem. When we explicitly refer to the ACF, we use "advocacy coalition" as an expression inter-changeable with policy community.

In the next section, we first trace the development of the EU social policy discourse from 1992 to 2007 to highlight the relative stability and rather evolutionary nature of its adaptation. But this is not self-evident if we consider the changes in the economic and political environment and the fluctuation of the "political centre of gravity" (Manow, Schäfer and Zorn 2008) of the EU. Then, in the third section, we identify a policy community in EU social policy, which is a source of policy stability and evolution. In this policy community, some academics have been playing a central role for years. In the fourth section, some examples concerning the "reach" of the EU policy community are presented and their possible effects are suggested. In the final section, we summarise our findings and arguments and discuss some implications.

The central contribution of this article is the identification of an EU social policy community at the very concrete, personal level. Another contribution is methodological. The article identifies this policy community using the data on neglected activities, such as the Presidency academic conferences or the advisory personnel and groups of the Commission and Member States.

\section{The development of the "European Social Model" discourse}

It is commonplace to use the phrase "European Social Model" in the discussion of the economic and social policies of the EU. It came to the fore especially after the launch of the Lisbon Strategy in the 2000 Lisbon European Summit. It is now well known that its declared aim was "to become the most competitive and dynamic knowledge-based economy in the world, capable of sustainable economic growth with more and better jobs and greater social cohesion" and one of the three aims was "modernising the European social model, investing in people and combating social exclusion". From these short quotes, it is clear that this strategy is an attempt to find a solution to the economic and social problems in a positive-sum combination of dynamic economic growth and social security.

Much has been written and discussed concerning the Lisbon Strategy's emergence, its novelty, and its effects. It is rather rare, however, to put this Strategy into a longer time frame. Below, based on an extensive reading of all the Presidency conclusions and important policy proposals in the social policy domain since 1993, it will be shown that the Lisbon Strategy is not so unique in terms of its contents. Rather, it should be seen within a continuous development at least since the Maastricht Treaty and its "evolutionary" character is to be emphasized.

(1) Beginning of the "Social Model" discourse (early 1990s)

Discussions over the "European Social Model" sometimes refer to a Green Paper 
of 1993 entitled "European Social Policy - Options for the Union" (COM (93) 551 final, 17 November 1993) as its starting point. In fact, this Green Paper is the first important policy document explicitly to use the word "Social Model". The issues dealt with in this Green Paper overlap with the current discussions, but the emphasis is put differently in some cases.

First, it is remarkable in the policy documents of this period that the complementary nature of the macro and micro aspects of the economy or economic reforms are stressed. For example, in the presidency conclusion of the 1993 Copenhagen European Council, which is usually noted for its adoption of the "Copenhagen Criteria" for the Eastern Enlargement, the priority is given to the employment problem against the background of the ratification failure in Denmark due to the referendum in June 1992. As a way out of a legitimacy crisis, the "European Council pledged the determination of the Community and its Member States to restore confidence through the implementation of a clear strategy ... to restore sustainable growth, reinforce the competitiveness of European industry and reduce unemployment (Presidency Conclusion, European Council in Copenhagen, 21-22 June 1993)". It is remarkable that the first instrument of the recovery is sought for in short-term fiscal measures: an increase in national-level investment and additional contributions to the European Investment Bank. In the medium to long term too, macroeconomic measures are listed as necessary to complement structural reforms.

Second, it is also characteristic of policy discourse in this period that the role of the structural fund is stressed. This is quite natural in view of the restricted policy instruments of the EU concerning economic and social policy at that time. But the emphasis on the direct intervention by the EU is more an expression of political will, which is hardly seen in the discourse of the 2000s.

Third, in terms of policy instruments, more hope is placed on the "Social Dialogue" procedures introduced in the Maastricht Social Protocol. In almost every policy document referring to the Social Model, the Social Dialogue is positioned centrally. Jacques Delors, then the President of the Commission, is known for his commitment to the establishment of this procedure and he had high hopes that the Social Dialogue could circumvent political deadlock at the Council and put pressure from domestic social actors on each national government.

In terms of policy contents, we should note that the issues discussed under the Lisbon framework were already taken up in this period. In the communication "Towards a Europe of Solidarity" (COM (92) 542 final, 23 December 1992), the commission said that the maximum support from citizens is only acquired when the development of the Social Dimension of integration is achieved, also pointing to the importance of participation by the trade unions, employer organizations and NGOs. It is also notable that this communication already highlighted social exclusion as a multi-dimensional phenomenon, based on the 1989 Council resolution. Further topics, such as the Danish model and Minimum Income Guarantee, were already referred to in this communication. Even the numerical employment target, which has become almost synonymous with the Lisbon Strategy, was already seen in this period in reference to the exclusion of women ("Community-wide Framework for Employment" (COM (93) 238 final, 26 May 
1993)).

There are also some differences in terms of policy content. In the famous white paper of the Delors era, "Growth, Competitiveness and Employment (COM (93) $700 \mathrm{final} / \mathrm{A}$ and B, 5 December 1993)", the reduction of working time and work sharing was given great prominence, but this has faded out in the later policy papers.

To summarize, social policy issues under the Lisbon Strategy were already present in the policy discourse of the 1990s. Still, there are differences in terms of policy instruments and policy contents. Further, the word "Social Model" itself disappears in other Commission Communications and presidency conclusions in this period, except for the 1993 Green Paper, which suggests that the discourse of "Social Model" was not yet firmly rooted. In the following years, however, the expression and terminology of the "Social Model" becomes an established framework in the EU social policy discourse.

\section{(2) Institutionalization of the "Social Model" (late 1990s)}

In the Essen European Council in December 1994, it was agreed to aim at labour-intensive growth, on which the Member States should submit an annual report from 1995. This was the starting point of the policy development leading to the Lisbon Strategy.

There are several points to be noted during this period. First, it is most remarkable that the phrase "Social Model" had secured a foothold in the EU social policy discourse. A typical example is the Communication "The Future of Social Protection: A Framework for a European Debate" (COM (95) 466 final, 31 October 1995). The paper begins with a clear sentence, "Social protection represents a fundamental component and a distinguishing feature of the European model of society", but the reform was under consideration "to replace the old rigidities with more flexibility, while at the same time maintaining this objective of solidarity". In the Communication "The European Employment Strategy: Recent Progress and the Prospects for the Future" (COM (95) 465 final, 11 October 1995) published three weeks previously, the aim was to realise both greater incentives to work and the social protection system, and the need to adapt the European model of society to the current situation was stated.

These policy initiatives resulted in agreement on the approaches to the creation of employment at the Madrid European Council in December 1995, including the necessity of both macro-economic policies and structural policies, co-operation of the Social Partners, a more efficient social protection system, the removal of labour disincentive, and so on. In 1996, the French President Jacques Chirac made a contribution, "Pour un modèle social européen", to the newspaper Liberation before the Turin European Council, which was taken up and discussed in the Inter-governmental Conference and the European Council. In his contribution, Chirac urged that employment be made a criterion for all policy measures and wanted more measures at the EU level than mere resolutions and reports. In this period, the "European Social Policy Forum" was held in 1996 and 1998, which invited the Social Partners and NGOs, and the development of various indicators was under way. In this way, the stake in European social policy became higher. 
Second, a policy orientation emerged from those discussions. It was a direct linkage between social policy and employment policy, represented by such expressions as "active social policy". This was an approach to maintain a certain level of social protection but encourage more participation in the labour market. This was epitomized well in the title of the Dutch Presidency Conference in 1997, "Social Protection as a Productive Factor".

Third, it is also of interest that we can already find the "flexicurity" issue, which was the main issue in 2006 and 2007, in this period. In the June 1996 document “Action for Employment in Europe: A Confidence Pact" (CSE (96) 1 final, 5 June 1996), issues like flexibility and security, diversified working hours and work-life balance were discussed and the expression "flexisecurity" can already be found. In the following documents, the couplet of "flexibility and security" was repeated numerous times (cf. COM (97) 102; Presidency Conclusions, Luxemburg Extraordinary European Council, 20 and 21 November 1997, Point $70)$.

\section{(3) The Launch of the Lisbon Strategy (2000-2004)}

The Lisbon Strategy, agreed upon by the March 2000 European Council and in which the modernization of the European Social Model was explicitly agreed, was not a sudden innovation. Rather, it was the culmination of the development of employment and social policy throughout the 1990s.

There are several background factors to the adoption of the Strategy. First, Europe was under favourable economic conditions reaching their peak in 2000 and the unemployment rate was going down. In other words, policy initiatives from the 1990s benefited from a following wind. Second, most Member States had left or centre-left governments, which will be discussed below. Third, a variety of policy initiatives had already accumulated throughout the 1990s. For example, the employment rate target of $70 \%$ was already on the table in the 1999 Communication "Community Policies in Support of Employment "(COM (99) 167 final, 21 April 1999), which also proposed the synergy of employment and economic policy, activation of the labour force, and life-long learning. This Communication was preceded by the European Council agreement in November 1997 and the Commission report in 1998 (COM (98) 572 final, 14 October 1998).

As a result, the "modernization of the European Social Model" became a political consensus at the EU level, the materialisation and the implementation of which was the next agenda. Substantially, the idea of the linkage between employment or social policy and economic policy was institutionalized in the EU social policy discourse; this has focused subsequent policy debates on the "balance" of both concerns, rather than an "either-or" type of debate.

\section{(4) Policy change under the Barroso Commission? (2004-)}

The centre-left had already fallen from power in 2002, and the liberal Portuguese Prime Minister Jose Manuel Barroso assumed the office of the Commission President in 2004, succeeding centre-left Romano Prodi. This moved the overall policy direction rightward towards more liberal economic policies.

In terms of social policy, this change did not lead to retrenchment, as in the case of the Member States in the 1980s and 1990s. Based on the institutionalized 
framing of the linkage between employment, social and economic policy, the shift in emphasis was evident and social policy became mainly directed at the creation of employment. In the European Council in March 2005, the Lisbon Strategy was re-launched, with a renewed focus on growth and employment. Active labour market policies and "making work pay" became the topics of the day. "Flexicurity", which was already found in late 1990s, came to the fore in the following years.

Although the duo of "flexibility and security" was already found before, "flexicurity" first appeared in the Presidency Conclusion in the March 2006 European Council. This European Council was preceded by the informal Hampton Court European Council held in October 2005. At this informal meeting, it was expected that there would be a big debate on the "Social Model". Barroso came with a Communication on "European Values in a Globalised World" (COM 2005525 final, October 20, 2005). He was expected to make an alliance with Blair toward further liberalization. The European Trade Union Congress issued a warning at the Tripartite Social Summit for Growth and Employment three days before the Summit, and the social NGOs presented their concerns with their own declarations (http://www.euractiv.com/en/ socialeurope/eu-debates-european-social-model/article-146338; Torreblanca 2005). From the EU social policy community, André Sapir submitted a paper "Globalisation and the reform of the European social models" to be presented at the ECOFIN Informal Meeting on 9 September. Here, Sapir pointed out that there were four, not one, "models" in Europe and the Anglo-Saxon Model was not the only alternative. The Scandinavian Model was almost as efficient, and with higher level of social protection.

In the end, a showdown was avoided. There was no discussion on the "Model(s)". The Social Platform, a loose coalition of the European Social NGOs, declared: "After a long battle the citizens are back at the core of the Lisbon Strategy. [...] For the last year Social NGOs have been fighting hard to save the social vision of Europe and we were all relieved to see that thanks to the Austrian Presidency the citizens' main concerns were back at the core of the Lisbon Strategy and the central role of social cohesion to achieve the EU objectives was recognised in the Conclusions of the Spring Summit. (Social Voices, 16, April-June 2006)" Even the double act of the Presidency/ Commission President could not break the policy consensus.

(5) Fluctuations in the Political Balance of Power and Continuity as a Puzzle As demonstrated above, the development of the Social Model discourse in these fifteen years is characterised more by "evolution" than "change". But what is the matter with "evolution"? It is argued below that this continuous development is not so self-evident in light of the changing political balance and coalitions within the Council and the rotating presidency system.

It is often pointed out that the Amsterdam Treaty and the ensuing social policy initiatives were possible under the general dominance of social democratic governments in European capitals. In 1997, the Labour Party under Tony Blair won a majority in the UK General Election of May, and Lionel Jospin of the French Socialist Party assumed the premiership as a result of parliamentary elections in May and June. Before that, Poul Nyrup Rasmussen had governed in 
Denmark since 1993, Wim Kok led the Dutch government since 1994, and the center-left "Olive" coalition won the 1996 Italian Election ousting Berlusconi. Center-left victories in the UK and France gave further momentum to that trend, which reached the pinnacle in the electoral success of the German Social Democrats under Gerhard Schröder in September 1998.

At first glance, this kind of political situation gives a plausible explanation for the launch of the Lisbon Strategy. It is impossible, however, to explain why there was no visible change after the end of center-left dominance.

Already in May 2001, the Italian electorate brought Silvio Berlusconi back into the Premiership. Danish Social Democrats lost power in November, and Jospin suffered disaster in the French presidential election in April 2002, failing to proceed to the second round. The downturn of the European center-left was most dramatically shown in the Dutch general election in May 2002. The Dutch Labour Party under Wim Kok, despite the internationally renowned "Dutch Miracle" and good economic performance (unemployment rate of 2.6\%, GDP growth around $3 \%$ ), suffered a historical defeat with its share of parliamentary seats almost halved.

If we view EU policy making mainly from an intergovernmental perspective, and assume that the political standpoint of each government is at least partly shaped by its partisan preferences, then these changes should also be reflected in policy changes in the EU. This is a plausible hypothesis considering the limited competence of the EU in this policy domain. But it was not the case, as has already been discussed. Even if we idenitfy a policy change, it occurred after Barrosso assumed the Commission Presidency in 2004. Even then, the change is not that of policy paradigm but of accent.

Beyond these anecdotal suggestions, let us proceed further to show the lack of obvious policy continuity by examining the political orientations of the Council and Presidency.

First, the political colour of the Commission President and the social policy Commissioner has been changing. After the mid-1980s, both centre-left and centre-right politicians took the office of the Commission President: Delors (1985-1994) from the French Socialists, Santer from the Luxemburg Christian Democrats (1995-1999), Prodi from the Italian "Olive" coalition (1999-2004) and Barosso from the centre-right Portuguese Social Democrats (2004-).

The partisan composition of the Council has been fluctuating as well, reflecting the change of government in the member states. Manow, Schäfer and Zorn (2008) show that the political center of gravity of the council lay generally to the right in the 1980s, then moved leftward in the 1990s and swung back again to the right after 2000. This partly explains the progress in EU social policy after the mid 1990s. As they point out, however, the partisan composition of the Council may indicate the general policy direction but cannnot fully explain respective policy initiatives. A typical example is the adoption of the Social Protocol attached to the Maastricht Treaty, which was supported by those member states like Germany, many of which were governed by center-right parties. 
The roles of the Presidency are not yet fully examined but it is certain that it has an important agenda-setting function. The presidency rotates every six months, in political colour as well. If we assume that every presidency exerts policy influence based on partisan orientation, policy change in a zig-zag manner would be possible.

Table 1 Political Orientation of the Council Presidency

\begin{tabular}{|ll|l|}
\hline 2000 & Portugal (left) & France (left) \\
\hline 2001 & Sweden (left) & Belgium (liberal + social democrat) \\
\hline 2002 & Spain (right) & Denmark (right) \\
\hline 2003 & Greece (left) & Italy (left) \\
\hline 2004 & Ireland(right) & Netherlands (right) \\
\hline 2005 & Luxemburg (right) & UK (left) \\
\hline 2006 & Austria (left) & Finland (right) \\
\hline 2007 & Germany (right) & Portugal (left) \\
\hline
\end{tabular}

To summarise, if we draw attention to the partisan orientations of the formal political organs, fluctuation rather than continuity is expected. True, political coalition building is quite important in explaining specific decision-making in the council. In that process, not just partisan orientation, but also national policy legacies (Johnson 2005) and transnational coalitions (Johansson 1999) are important factors.

It is not the case, however, in the policy initiatives at the EU level. Besides the coalition building at the decision phase, this article contends that policy-making or the formulation of policy initiatives is also important. This is because these initiatives are monopolized by the Commission, and a coalition most effectively works in the revision and decision of already tabled policy initiatives.

\section{Identifying the EU Social Policy Community}

In spite of possible political fluctuations, it is the "Social Model" advocacy coalition, including the Directorate-General (DG) for Employment, civil society organizations, and, last but not least, academics, which nurtures the evolution of the "Social Model" discourse.

\section{(1) Bureaucratic source of continuity}

From where does this continuity emerge? Part of the answer lies in bureaucratic continuity.

The Commissioners dealing with social policy are; Manuel Marin from the Spanish Socialists, Vasso Papandreou from the Greek New Socialists, Padraig Flynn from Irish Fiana Fáll, Anna Diamantopaulou again from the Greek New Socialists, and Vladimir Spidra from the Czech Social Democrats. In comparison with the more general partisan composition, the social policy commissioner comes from those parties broadly friendly to social policy.

Further, examination of the high officials in the DG for Employment shows another source of continuity (the following analysis is based on various annuals 
of the Commission, namely Annuaire de la commission de la communauté économique européene, Organigramme de la Commission des Communautés europeenes, Who's who in the European Union?). First we examine the Director-General, the chief on the side of the DG bureaucrats. Jean Degimbe had served for sixteen years since 1976 (http://wwwarc.eui.eu/ech/binFR/CreaInt. asp? $r c=$ INT-ECH691). He was a long-serving European official, recruited to the ECSC High Authority by Christian-socialist Roger Raynaud, who was from the French Christian Union CFTC. He then served under Vice President Raymond Barre and President Ortoli. During his time in office, the line-up of the high officials was stable. After a three-year vacancy, the post was filled by Allan Larsson from 1995 to 2000. He was a Swedish Social Democrat, who had served as a President of the Swedish Labour Market Office and the Minister of Finance (http://www.varnamo.se/naringsliv/gottomplats/ambassadorer/allanlarsson.4. 18ff2710e077ef560800010591.html). From 2000, Odile Quintin served for six years. She entered the commission in 1971 directly after her graduation from University. After experience working in the DG for Agriculture and the DG for External Affairs, she worked in the DG for Employment from 1982 (http://www. oecd.org/speaker/0,3438,fr_21571361_35042830_35287523_1_1_1_1,00.html). Since 2005, Nikolaus van der Pas has been Director-General. After working in German and Dutch private companies, he came to the Commission in 1963 and spent many years in Public Relations and External Affairs. His previous job was the Director-General of the DG for Education (http://ec.europa.eu/dgs/ employment_social/organigram/cv_vanderpas_en.pdf).

The Deputy Director-General was created in 1993. Hywel Ceri Jones first occupied this position for five years. He had also been working in the Commission for many years, mostly in Education and Employment. He became the Director of the Education, Vocational Training and Youth Policy in 1981 (Organigramme, December 1981), then served as a member of a task force on educational problems before assuming the Deputy Director-General position in 1993. After him, Quintin was Deputy Director General for two years, and Karl-Johan Lonnroth succeeded her after 2000. He was a genuine social policy official, who had worked in the Finnish Ministry of Labour for twenty years and then moved to the ILO before coming to the Commission in 1996 (http://ec. europa.eu/civil_service/docs/directors_general/lonnroth_en.pdf). Since 2005, Lenia Samuel has served, His previous position was the General Secretary of the Cypriot Ministry of Labour and Social Security, where he had worked since his university graduation (http://ec.europa.eu/civil_service/docs/directors_general/ samuel_en.pdf).

As these examples show, most top officials in the DG for Employment already had many years of experience, whether in the case of internal promotion within the Commission or external transfer from the Member States. This guarantees policy continuity to some extent.

A few remarks are in order. First, as exemplified by the current Director General, some top officials did not have previous experience in the social policy field. Among nine Directors of the DG for Employment (as of the end of 2007), only two had worked for the DG for more than ten years. New appointments at the Director level often include promotion from other DGs, which means that there is no closed track for social policy bureaucrats. 
Second, "Brussels" is often described as a bureaucratic monster in the popular press, but the Commission in not so gigantic in reality. As of September 2009, about 25,000 regular employees worked for the Commission, 600 for the DG for Employment. Among them, however, those bureaucrats influential in policy-making (AD) only numbered around 340 (http://ec.europa.eu/civil_ service/docs/bs_dg_category_en.pdf). The DG is composed of nine Directorates, which have about four Divisions, and one division has around ten bureaucratic policy makers. Considering the huge task of co-ordination with other DGs, EU Institutions and the Member States, one can hardly say that the DG is equipped with enough human resources to monopolize policy formulation.

Thus, the Commission cannot guarantee policy continuity by itself. In fact, it is often pointed out that the Commission is rather open to external policy advice (Smith 2004; Borras 2007; Mazey and Richardson 2006; Degger and Kambeck 2007; Interview with Roshan Di Puppo, Philippe Pochet). We have to investigate further to find external actors in the advocacy coalition.

\section{(2) Academics constituting the policy community}

In identifying the EU social policy community, this article focuses on external, mainly academic actors. They contribute to the development in the EU social policy through several channels.

\section{a. Standing advisory organs}

First, we examine various institutionalised advisory organs surrounding the Commission. This kind of official think-tank was first established by the Delors' initiative as the "Forward Studies Unit" in 1989. The unit was composed of fifteen members and was supposed to submit a report on important issues directly to the Commission President (http://ec.europa.eu/comm/cdp/mission/index_en. $\mathrm{htm})$. Activities of this unit included publication of "Europe 2010" and the preparation of the White Paper on European Governance.

In May 2001, the Prodi Commission established the Group of Policy Advisers (GOPA) to succeed the Forward Studies Unit. The GOPA had six divisions, Economy, Science and Technology and Society, Foreign Affairs, External Relations, Dialogue with Religions, Churches and Humanisms and Public Opinion and Communication Strategies. The Group of Economic Analysis was chaired by the director of the Group of Policy advisers and included "six executive members" and the executive director, Andre Sapir. Except for Sapir, these were officials from the Commission. The Group had twenty-five "external members", which was composed of university professors and researchers in the think-tanks and economic analysis institutions. Among them, some experts are notable by their continued presence thereafter; Jean Pisani Ferry, then Executive President of the Conseil d'Analyse Economique, Maria Joao Rodrigues, Special adviser to the Portuguese Prime Minister and Professor of Economics at Lisbon University, and Klaus Zimmermann, President of the German Institute for Economic Research. In particular, Rodrigues' role is important, leading Zeitlin (2007) to call her "Mother of the OMC". She had already participated in the so-called Gillenhammer Working Party on industrial change, which was set up by the 1997 Luxemburg European Council. 
In 2005, the Group of Economic Analysis was further re-organized into the Group of Economic Policy Analysis (GEPA) as a part of the Bureau of European Policy Advisers (BEPA). The Bureau had three expert groups, the declared aim of which was that " $[\mathrm{t}]$ hese expert groups bring together officials from other Commission services and selected external experts from academia, policy centres and the business community". In the GEPA, external members were reduced in number to twelve and included Pisany-Ferry and Sapir.

In the BEPA, the "Group of Societal Policy Analysis" was established as a new expert group dealing with social policy. This group was expected to give advice on the reform of the European Social Model. The Group was chaired by Loukas Tsoukalis, then Professor of Oxford University, and included eleven academics. It is remarkable that most of these eleven members were broadly social democratic advocates of the modernization of the European Social Model, and have already taken part in EU policy formulation.

G $\phi$ sta Esping-Andersen and Maurizio Ferrera have already been engaged in these activities as seen in the academic report submitted to the Presidency. Fritz Scharpf, former Director of the Max-Plank-Institute of the Study of Society, was a well-known adviser to the German Social Democrats. Francois Bourguignon was former vice-president of the World Bank, who belonged to the group "gauche-en-europe" which was established by Michel Rocard and Dominique Strauss-Kahn of the French Socialist Party (http://www.gauche-en-europe.org/ IMG/pdf/cos-2.pdf). Besides Bourginon, Esping-Andersen and Pisany-Ferry were members of the academic council of "gauche-en-europe". Manuel Castel participated in the expert conferences preceding the Lisbon European Council in 2000, and Julian Le Grand was adviser to Tony Blair on Health Policy. Jitka Rychtarikova was special adviser to the Employment Commisionar Spidra. Zimmermann headed the Berlin Economic Institute, known for its closeness to the trade unions, and changed its policy orientation towards a more liberal direction (Forschungsprovinzialismus und okonomischer Mainstream, http:// www.bdwi.de/forum/archiv/archiv/97825.html; Frankfurter Rundschau, 31. Mai 2003, "Mit Frührente muss Schluss sein").

Two other members, Frans Van Vught and João Borges de Assuncao, can be called "liberal". The former was member of the Dutch liberal D66 (http://www. observant.unimaas.nl/default.asp? page $=/ \mathrm{jrg} 24 / \mathrm{obs} 6 / \mathrm{art} 45 . \mathrm{htm})$ and member of the advisory group to Prime Minister Balkenende, and the latter was economic adviser to Barrosso, when he was prime minister of Portugal.

In recent years, Roger Liddle, a Principal Advisor in the BEPA, has played a most visible role as the co-author of the policy paper "Europe's Social Reality: A Consultation Paper from the Bureau of European Policy Advisers", submitted to the 2007 Spring European Council. A public consultation was launched based on this policy document, which resulted in the communication "Opportunities, Access and Solidarity: Towards a New Social Vision for 21st Century Europe" (COM(2007)726) and a Commission Staff Working Paper (SEC(2008)1896). He was a special advisor to Tony Blair on European Policy from 1997 to 2004 and also known for co-authoring a book with Peter Mandelson entitled The Blair Revolution, which was famous for being "the nearest approximation to a manifesto of New Labour's modernisation programme (Forey 2000, 99)” (http:// 
www.cumberland-news.co.uk/news/viewarticle.aspx?id=567433). His presence in the Barrosso Commission shows the shift in emphasis towards a more liberal orientation within the policy community.

\section{b. Special advisory organs}

Besides these standing groups, it is quite commonplace to call up an advisory group for a specific policy objective. The "High Level Group on Industrial Relations" was set up following the Commission's Communication on the Social Agenda of June 2000 and submitted its report in 2002. It was chaired by Rodrigues and ten members, among which three members each came from the labour unions and the employers. Four academic members included Rodrigues and Jelle Visser, the co-author of the book A Dutch Miracle. The "Employment Task Force", set up in 2003 under Wim Kok's chiarmanship, had seven members including five academics. Rodrigues and Günther Schmid, who had advocated the introduction of the element of flexibility in the German labour market in reference to the Dutch and Danish experiences, belonged to this Task Force. The "High Level Group on the Future of Social Policy in an Enlarged European Union" worked from 2002 to 2004. It was composed of five members, among whom were Rodrigues and Anthony Atkinson, who had worked in EU-related activities since the 1990s and co-authored a presidency report on social inclusion. A further eight experts who provided a substantial input were named, including Sapir and Zimmermann.

The existence of a rather stable policy community can be seen in the drafting process of the Constitutional Treaty. Working Group Nine of the Convention, charged with social policy, conducted hearings and invited Diamantopoulou (then Employment Commissioner), Frank Vandenbrouck (former Flemish Minisgter of Social Affairs), Atkinson and Olivier Dutheillet de Lamothe, chair of the "High Level Group on the future of social policy in an enlarged European Union".

As was shown above, special advisory organs include several, so-to-speak "core" members like Rodrigues, Sapir and Atkinson. The reports submitted by these advisory organs usually function as the baseline for subsequent policy initiatives and their influence cannot be underestimated.

In contrast, although similar in its objective, the "High-level Group on the Lisbon Strategy", set up in 2004 and releasing its mid-term review in 2005, was different in its composition. As in the case of the "Employment Task Force", it was chaired by Wim Kok, but it was mostly composed of parliamentarians, employers and trade union leaders. In fact, some academics were included, but they were specialists on Environment and Economics. The resulting "Kok Report" advocated streamlining of the Lisbon Strategy, and is sometimes criticized as a setback for the social aspects of the Strategy. As is seen in the composition of the Group, this report came from outside of the policy community and it is the reason why the orientation of the report is somewhat different from previous policy documents.

\section{c. Presidency conferences}

In addition to these formal advisory organs surrounding the Commission, more diffuse activities by the Presidency have contributed to the accumulation of the 
"Social Model" discourse. Here, we focus on the Presidency academic conferences and reports submitted to it. As in case of the White Papers and the Green Papers, which have been paid due attention in EU research, these academic reports submitted to the Presidency have played a non-negligible role in influencing policy directions. Below is the list of academic conferences with substantial reports.

Table 2 Reports submitted to the Presidency Conferences and their Main Authors

\begin{tabular}{|c|l|l|}
\hline & \multicolumn{1}{|c|}{ Presidency } & \multicolumn{1}{c|}{ Authors } \\
\hline Mar. 2000 & Portugal & Ferrera, Hemerijck, Esping-Andersen \\
\hline Sep. 2001 & Belgium & Esping-Andersen, Gallie, Hemerijck, Myles \\
\hline Jun. 2003 & Greece & $\begin{array}{l}\text { Amitsis, Berghman, Hemerijck, Sakellaropoulos, } \\
\text { Stergiou, Stecvens }\end{array}$ \\
\hline Jul. 2005 & Luxembourg & Atkinson, Cantillon, Marlier, Nolan \\
\hline Nov. 2006 & Finland & Kvist, Saari, Le Grand, Hemerijck, and others \\
\hline Jun. 2007 & Portugal & $\begin{array}{l}\text { Rodrigues, Hemerijck, Schmid, Berghman } \\
\text { others }\end{array}$ \\
\hline
\end{tabular}

It is clear that the membership of the policy community surrounding the Commission also formed the core of these Presidency conferences. Judging from the authors, the Presidency may have some say in their selection, as is most clearly seen in the report to the Greek presidency. It is also notable that the Dutch (second-half of 2004) and Spanish (first-half of 2002) Presidencies did not convene academic conferences related to social policy. It may be the case that the Presidency simply ignores those policy areas not conforming to their own policy preferences.

\section{d. Academics as policy promulgators}

The core members of the EU social policy community, academics participating in the discourse accumulation process, then amplify and promulgate the "Social Model" discourse through their status as university-based researchers. One of the examples of these functions is the publication of the reports submitted to the Presidency conferences by academic presses. The 2000 report by Ferrera, Hemerijck and Esping-Andersen was scheduled for publication by the Oxford University Press, as well as the 2001 report by Esping-Andersen and others. The 2003 report of the Greek Presidency conference was published by Hart Publishing, and the 2006 Finnish conference report and the 2005 Luxembourg report were published by Polity Press. Usually, the EU policy documents are published by the Office for Official Publications of the European Communities in Luxembourg. By inviting renowned academics as the authors, these reports can be distributed through academic publishers.

Further, apart from those conferences convened by the EU and national governmental institutions, these academics have played an active and important part in conferences and publications, which further accelerate the diffusion of the Social Model discourse. For example, the British third-way think-tank "Policy Network" has organized a series of conferences and published the contributions as a book entitled Global Europe, Social Europe in 2006 with the Polity Press. 
This book provides an all-star cast of the EU social policy community with Hemereijck, Tsoukalis, Ferrera, Liddle and Lönnroth as contributors.

Part of the policy community has also participated in the EU research policy process. The DG for Research has set up the Advisory Group on "Social Sciences and Humanities in the European Research Area", to provide advice regarding the Sixth Framework Programme for Research and Technology Development (RTD) (from 2002 to 2006) and the European Research Area in Social Sciences (ftp://ftp.cordis.europa.eu/pub/citizens/docs/advisory_group_members.pdf). One of the tasks of this Advisory Group was to identify the research priorities in the seventh thematic priority, "Citizens and Governance in a knowledge based society", in the Seventh Framework Programme. Fifteen members of this Group include Rodrigues, Gallie, and Thomas Meyer, who is one of the most active academics in the discussion programmes of the German Social Democratic Party. Four members of this Advisory Group also belong to the expert group called "Lisbon Agenda", which has been organized by Rodrigues (http://www. mariajoaorodrigues.eu/lisbon-agenda/group/). In the "Lisbon Agenda", Castel, Berghman and Robert Boyer have been taking part.

Faced with a lack of enthusiasm in EU institutions, academics in the policy community sometimes stimulate the debate from outside. The "Sapir Report" in July 2003 is an example. Prodi asked Sapir in July 2002 to submit a report on the achievement of the Lisbon Strategy goals and the eastern enlargement. It resulted in a report authored by Sapiar and Pisany-Ferry (http://www.euractiv. $\mathrm{com} / \mathrm{en} /$ future-eu/controversial-expert-report-upsets-commissioners/article114693). However, the report was so critical of the cohesion policy and the CAP that the Commissioners on regional and agricultural policy made highly negative responses on the report, making its adopition as a formal "report" impossible. Prodi avoided commenting, saying that he was in no position to do so. Further, at the time of publication, the Convention on the Future of Europe was at its final stage and monopolized political attention. Thus, the report did not stimulate any political dynamism.

Against this silence, the oldest think-tank in Brussels, the Center for European Policy Studies, published a policy paper entitled "Beyond the Sapir Report" to stimulate the debate (http://www.euractiv.com/en/innovation/europedeliver-growth-sapir-report/article-132113). Sapir and Pisany-Ferry responded and reiterated their recomendations as a policy paper Last Exit to Lisbon in 2006 (Pisany-Ferry and Sapir 2006).

In general terms, too, the wall separating the inside and outside of the EU official institutions is not so high; this is not only in terms of policy but also personnel. On the one hand, as mentioned above, Jones, who had served as Deputy Director-General from 1993 to 1995, became the president of the executive committee of a Brussels-based think-tank, the European Policy Centre, in 2001 and worked there for six years (http://www.epc.eu/PDF/Feb2007.pdf). On the other hand, Sapir and Pisany-Ferry, now working outside, were advisers to the Director General of the DG for Economic and Financial Affairs from 1990 to 1993. 


\section{(3) Discussion: the EU social policy community and the Advocacy Coalition Framework}

As shown above, the EU social policy formulation process is accompanied by the input and dissemination activities of academics and external policy experts. The commission itself often invites them as policy advisers and academic contributors. They also work outside the formal institutional framework, which helps accumulation and institutionalization of the "Social Model" discourse. It is notable that there are some "core" members, like Rodrigues, Liddle and Hemerijck. Their political orientation is relatively similar, that of social democratic modernization. This policy community functions as the advocacy coalition at the EU level, which has enabled continuous policy development over these last fifteen years.

In the Advocacy Coalition Framework, it is assumed that there are some contending advocacy coalitions in a policy subsystem, whose interactions and resulting policy changes are the focus of analysis. In the case of the EU's social policy, we can find only one advocacy coalition around the DG for employment.

Why this anomaly? There are a few possible reasons. First, a stable policy community is necessary as the EU institutional structure is notoriously fragmented. To reach consensus among many players wielding a veto and with different partisan orientations and national interests, the policy needs to be as "neutral" as possible. This necessitates moderate policy orientations, which are supported by the relatively homogeneous advocacy coalitions of bureaucrats and policy experts.

Second, policy formulation is less politicized due to diminished party political struggles at the EU level. In the case of nation-states with fragmented institutional structures as Germany and the United States, the political executive (US) or the political parties (Germany) can give a political orientation from outside the bureaucratic machinery by way of political appointments or promotion based on partisanship. This brings the party politics inside the policy subsystem. Minorities in the policy subsystem can depend on the power of political actors to attain policy change, and the political actors can take political ownership of the alternative policy ideas of the minority. At the EU level, party political struggle is less noted, although one can see a growing politicization in the European Parliament. Further, the executive organ, the Commission, is based on the Grand Coalition of the left and the right, and it is expected that the Commissioner works for the "European" interest, neither national nor partisan.

Third, there is less incentive for political actors to raise a voice at the European level. As the EU institutions are endowed with weak political power and resources, they must rely on "soft" methods to achieve many of the goals raised in the Lisbon Strategy. Thus, those political actors who have opposing policy orientations to the EU social policy community can simply "exit" from the EU-level policy subsystem and move to the Member State level, stopping the policy initiatives at the Council or ignoring them at the implementation stage.

As a result, the political dynamics over policy change unfold more between the policy subsystems, rather than inside the policy subsystem. 


\section{The reach of the policy community}

As is suggested in the previous section, it is not self-evident that the EU social political community, or the advocacy coalition, extends over the institutional layers. It is theoretically justifiable to presuppose that an advocacy coalition can be formed over the different political levels. It is an empirical question, however, if it really does include the personnel from different levels and take effect at all levels. Below, two examples are provided where the EU social policy community can have a policy effect and reach beyond Brussels. At the same time, it is also suggested that this is not always the case.

\section{(1) The Presidency as a "window of opportunity"}

The first example is the role of the Presidency. As the EU has weak social policy competence, political backing is necessary for the initiatives based on the Social Model discourse to materialize. The Council Presidency sometimes serves that purpose.

Zeitlin $(2007,132)$ explains the establishment of the Lisbon Strategy through the activities of the high officials of the DG for Employment. According to him, the then Director-General Larsson and his Deputy Quintin had recognized and theorized the European Employment Strategy (EES) quickly as an innovative approach to EU governance prior to the March 2000 Lisbon extraordinary European Council. In other words, the Portuguese Presidency took the policy initiatives already under way inside the EU bureaucracy and successfully introduced a policy innovation.

In this Lisbon Council, the "active welfare state" concept was introduced (Presidency Conclusions, Lisbon European Council, 23 and 24 March 2000, para 24-34). This was followed by its implementation in the form of the Pension Open Method of Coordination (OMC) introduced under the Belgian Presidency in 2001. Here, the political initiative of the Belgian Minister of Social Affairs, Vandenbroucke, was important. Vanhercke (2006) tells an interesting story about it:

During the spring of 2001, the Belgian Minister for Social Affairs and Pensions, Frank Vandenbroucke, preparing at that time "his" EU Presidency later that year (July-December 2001), received a special visitor in his cabinet. Odile Quintin, then Director General of DG Social Affairs of the European Commission, was invited to share her views on the priorities of the future Belgian Presidency ... and she altered them. Indeed, up to that point Frank Vandenbroucke, advised by his Presidency Task Force, wanted to limit the agenda to, first, further developing EU co-operation with regard to social inclusion and, second, finding agreement on the modernisation of Regulation 1408/71. Obviously, Odile Quintin had made a correct judgement when she firmly insisted on speaking directly to the minister, and not to the Chief of Cabinet or the Task Force: 60 minutes of discussion later, the "Social Affairs" side of the future Belgian Presidency had a third priority, suggested by Odile Quintin: preparing the open method of co-ordination on pension. (Vanhercke 2006, based on an interview with Frank Vandenbroucke, 27 February 2006)

This is another example of a political initiative by the Presidency making internal 
policy development materialize. There is a further aspect to this story. Vandenbroucke temporally retired from public office due to a political scandal. During this time, he was enrolled at Oxford University and earned a D.Phil. from the Faculty of Social Studies. His advisor at Oxford was Atkinson, which means that Vandenbroucke had already been close to the "core" of the EU social policy community. Thus, it is only natural that he took up the policy initiative proposed by Quintin. He insists that he had devised the Dutch expression de actieve welvaartstaat (active welfare state), which departs from the Bismarckian welfare state but is different from the Blairite "Third Way" (Vandenbroucke 2003).

In this way, the Social Model discourse can be translated into concrete policy with the help of the Presidency. Seen from the opposite direction, these examples show that pre-existing advocacy coalitions and the institutionalized discourse enabled "small" countries to take bold steps in policy making, without the use of voting or economic power.

\section{(2) Spill-over of the discourse to the national level}

In some cases, a part of the EU social policy community is directly linked to the national policy community. This will serve as an institutional channel for "soft" Europeanization.

For example, the French government's Centre for Strategic Analysis (Centre d'Analyse strategique) was established based on the decree of June 2006, and one of its primary tasks was to realise the objectives of the Lisbon Strategy (http:// www.strategie.gouv.fr/rubrique.php3?id_rubrique=2). It had five divisions, among which the Division of Labour, Employment and Vocational Training was headed by Yves Chassard, who participated in the discussions of the High Level Group on Social Policy as an external expert. Soon after its launch, the Centre convened a workshop entitled "Social Europe" in October (Workshop 《Social Europe》. The Social Dimension of the European Union: What are the Prospects?, 23 October 2006. http://www.strategie.gouv.fr/IMG/pdf/ ACTESEuropeSociale.pdf). Many of the EU social policy community members were invited, including Liddle, Ferrera and Tsoukalis.

It is already been noted that Rodrigues was special adviser to the Prime Minister of Portugal during its Council Presidency. Hemerick, author of many of the policy documents, has been a member and the director of the Academic Advisory Council for the Dutch Government (Wetenschappelijke Raad voor het Regeringsbeleid). He convened a symposium entitled "Toward a New Social Investment Agenda: The Future of the Dutch Welfare State" (Naar een nieuwe sociale investeringsagenda: De toekomst van de Nederlandse verzorgingsstaat), to which Vandenbroucke was invited as a speaker.

\section{(3) Limits of the EU social policy community}

In other cases, however, the accumulated policy discourse does not take effect or is even just ignored. For example, the German Government submitted its National Strategy Plan in 2005 to both houses of its parliament for the purpose of discussion. The Lower House bundled this draft report together on the agenda with other social policy legislative proposals, and the debate was concentrated on these proposals without any comment on the National Strategy Report (Deutscher Bundestag, Stenographischer Bericht, 16. Wahlperiode, 32. Sitzung, 6. 
April 2006). The Upper House, with its opposition majority, made a resolution that just criticized the government and said nothing on the Report's content (Bundesrat Drucksache, 413/1/05).

The impact of the social policy OMC is rather limited, according to the existing empirical research (Zohlnhöfer and Ostheim 2005; Kröger 2006; Natali 2007, Ervik 2006). In Last Exit to Lisbon, authored by Pisany-Ferry and Sapir (Pisany-Ferry and Sapir 2006), the commitment of four types of actors, namely the parliament, social partners, civil society and follow-up institutions, was ranked. With the exception of Estonia, most countries could score only half, which showed a continued lack of interest and commitment by the national actors.

Thus, we cannot say that the EU social policy community always matters. Only in some cases and under certain conditions can the policy community extend beyond Brussels and take real effect on policy. This image rather resembles the "policy stream" image of Kingdon (1984). The EU policy process and the Member State policy process are usually autonomous and rather isolated. In some cases, due to external pressure, political entrepreneurship and other reasons, the two processes become inter-connected. Until that point, the general direction of the policy subsystem is already determined at the EU level. Still, in the case of "soft" policy diffusion, Member States can resist influence by opposing or ignoring the input from the EU level. In this image, Europeanization does not proceed continuously; it is more intermittent. We may call this image "punctuated Europeanization”.

\section{Summary and implications}

Let us summarise our findings in three points. First, the development of EU social policy is continuous and evolutionary, in spite of a changing political climate. Second, we can identify a stable EU social policy community behind this evolution. In this community, several academics have played important roles as the generators of policy ideas and their promulgators. Third, the "reach" of the EU policy community is usually limited. It needs some political ally or favourable conditions for its policy ideas to take effect.

These findings have several implications for further research. First, Europeanization research should pay more attention to these "soft" channels of influence, especially when the formal competence of the EU's institutions is weak. For that purpose, we should also expand our view and include seemingly non-political actors like academics. Second, research on Europeanization has tended to focus on "decisions", but we should take a longer-term perspective, as recommended by the ACF, including policy formulation and implementation. A short-sighted view might mistake a policy idea with a long incubation period for a recent innovation, as in the case of flexicurity. Third, the ACF may serve as a useful frame of reference, but it needs some calibration in order to be applied to the EU policy process. In particular, the fragmented and the multi-level nature of the EU and the multiple veto-points should be carefully examined. Finally, there are still unexplored sources for the examination of the EU policy process; when we want to know more about informal and soft aspects of governance, we should explore non- or under-utilized materials and devise methods for their analysis. 


\section{Bibliography}

Amitsis, Gabriel, Jos Bergman, Anton Hemerijck, Theodores Sakellaropoulos, Angelou Stergiou, and Yves Stevens. 2003. Connecting Welfare Diversity with the European Social Model?, Report submitted to the Greek Presidency of the European Union.

Büchs, Milena. 2007. New Governance in European Social Policy: The Open Method of Coordination. Basingstoke: Palgrave.

Borras, Susana. 2007. The European Commission as Network Broker. European Integration online Papers, 11(1).

Dagger, Steffen, and Kambeck, Michael (eds.). 2007. Politiberatung und Lobbying in Brüssel. Wiesbaden: VS Verlag für Sozialwissenschaften.

De la Porte, Caroline, and Adao e Silva, Pedro. The Informal Council as an Institutionalised Feature of the European Policy-Making Landscape: Ideational Forum, Agenda-setter or Policy-decision Forum? In: Ministerio do Trabalho e da Solidariedade Social (2007), 145-163.

Deganis, Isabelle. 2006. The Politics behind Consensus: Tracing the Role of the Commission within the European Employment Strategy. Journal of Contemporary European Research, 2(1), 21-40.

Ervik, Rune. 2006. European Pension Policy Initiatives and National Reforms: Between Financial Sustainability and Adequacy. Stein Rokkan Centre for Social Studies Working Paper, 10.

Esping-Andersen, Gosta, Duncan Gallie, Anton Hemerijck, and John Myles. 2001. A New Welfare Architecture for Europe?, Report submitted to the Belgian Presidency of the European Union.

Ferrera, Maurizio, Anton Hemerijck and Martin Rhodes. 2000. The Future of Social Europe: Recasting Work and Welfare in the New Economy, Report prepared for the Portuguese Presidency of the EU.

Forey, Michael. 2000. The British Presidency: Tony Blair and the Politics of Public Leadership, second edition. Manchester: Manchester University Press.

Ideman, Timo and Keleman, R Daniel. 2006. New Modes of Governance, the Open Method of Coordination and other fashionable Red Herring. Perspectives on European Politics and Society, 7(1), 108-123.

Johansson, Karl Magnus. 1999. Tracing the Employment Title in the Amsterdam Treaty: Uncovering Transnational Coalitions. Journal of European Public Policy, 6(1), 85-101.

Johnson, Ailish. 2005. European Welfare States and Supranational Governance of Social Policy. Basingstoke: Palgrave.

Kendall, Jeremy and Anheier, Helmut K. 1999. The Third Sector and the European Policy Process: An Initial Evaluation. Journal of European Public Policy, 6(2), 283-308.

Kingdon, John. 1984. Agendas, Alternatives and Public Policies. Boston: Little, Brown.

Kroeger, Sandra. 2006. When Learning Hits Politics Or: Social Policy Coordination Left to the Administrations and the NGOs? European Integration online Papers, 10(3).

Leibfried, Stephan. 2005. Social Policy: Left to the Judges and the Markets? In: Wallace, Hellen, William Wallace and Mark A. Pollack, Policy-Making in the European Union, Fifth Edition. Oxford: Oxford University Press, 2005, 243-278.

Mailand, Mikkel. 2006. Coalitions and Policy Coordination: Revision and Impact of the European Employment Strategy. Copenhagen: DJØF 
Publishing.

Ministerio do Trabalho e da Solidariedade Social (Portugal) (eds). 2007. Perspectives on Employment and Social Policy Coordination in the European Union. Lisbon: Centro de Informacao e Documentacao.

Manow, Philip, Schäfer, Armin, and Zorn, Hendrik. 2008. Europe's Party-Political Center of Gravity, 1957-2003. Journal for European Public Policy, 15(1), 20-39.

Mazey, Sonia, and Richardson, Jeremy. 2006. Interest Groups and EU Policy-making: Organisatonal Logic and Venue Shopping. In: Jeremy Richardson (ed.), European Union: Power and Policy-making, 3rd edition. Oxford: Routledge, 247-268.

Natali, David. 2007. Pension OMC's Influence on National Reforms. NEWGOV, 1/D47. <www.eu-newgov.org/database/DELIV/D01D47_WP_Pension s_ OMCs_influence_on_national_reforms.pdf $>$

Pierson, Paul, 1996. The Path to European Integration: A Historical Institutionalist Analysis. Comparative Political Studies, 29(2), 123-63.

Pisani-Ferry, Jean, and Sapir, Andre. 2006. Last Exit to Lisbon. Bruegel Policy Contribution. <www.bruegel.org/download/parent/29-last-exit-to-lisbon/ file/385-last-exit-to-lisbon-english $>$

Sabatier, Paul A. 1988. An Advocacy Coalition Framework of Policy Change and the Role of Policy-Learning therein. Policy Sciences, 21(1), 129-168.

1998. The Advocacy Coalition Framework: Revisions and Relevance for Europe. Journal of European Public Policy, 5(1), 98-130.

Sabatier, Paul A. and Hank C. Jenkins-Smith, ed. 1993. Policy Change and Learning: An Advocacy Coalition Approach. Boulder: Westview.

Sabatier, Paul A. and Christopher M. Weible. 2007. The Advocacy Coalition Framework: Innovations and Clarifications. In Theories of the Policy Process, ed. by Paul A. Sabatier. Boulder: Westview, 189 - 220.

Smith, Andy (ed.). Politics and the European Commission: Actors, Interdependence, Legitimacy. London: Routledge.

Torreblanca, José I. 2005. Five Specific Questions for General Disagreement: The Hampton Court Summit and the UK Presidency. <www.realinstitutoelcano. org/wps/portal/rielcano_eng/Content?WCM_GLOBAL_CONTEXT=/ elcano/Elcano_in/Zonas_in/ARI\%20126-2005>

Vandenbroucke, Frank. 2002. The EU and Social Protection: What Should the European Convention Propose. MPIfG Working Paper, 02/6, Max-Plank-Institut fur Gesellschaftsforschung.

Vandenbroucke, Frank. 2003. Promoting Active Welfare States in the European Union. Lecture held at University of Wisconsin, Madison, 30 October 2003. $<$ eucenter.wisc.edu/Publications/vandenbrouckeWI.htm>

Vanhercke, Bart. 2006. Variations in Institutionalisation of Hybrid Social Protection OMC's: The Choice for Non-Constitutionalisation and the Emergence of 'Hard-Soft Law'. Paper presented at the 2006 ESPANET Conference. Bremen, 21-23 September 2006.

Wendler, Frank. 2005. Soziales Europa und demokratische Legitimität: Die Institutionalisierung der EU-Sozialpolitik aus demokratietheoretischer Perspektive. Baden-Baden: Nomos.

Zeitlin, Jonathan. 2005. The Open Method of Co-ordination in Action: Theoretical Promise, Empirical Realities, Reform Strategy. In: Zeitlin and Pochet (2005), 447-503.

Zeitlin, Jonathan. 2007. "A Decade of Innovation in EU Governance: The 
European Employment Strategy, the Open Method of Coordination, and the Lisbon Strategy" In Ministerio do Trabalho e da Solidariedade Social (2007), 129-144.

Zeitlin, Jonathan, and Pochet, Philippe (eds.). 2005. The Open Method of Co-ordination in Action: The European Employment and Social Inclusion Strategies. Bruxelles: P.I.E. - Peter Lang.

Zohlnhöfer, Reimut, and Ostheim, Tobias. 2005. Paving the Way for Employment? The Impact of the Luxembourg Process on German Labour Market Policies. Journal of European Integration, 27, 147-167.

\section{Interviews}

Roshan Di Puppo, Director of Social Platform. Brussels, 10 March 2008.

Philippe Pochet, Director of the European Trade Union Institute for Research, Education and Health and Safety. Brussels, 11 March 2008. 